\title{
Maps and Tables
}

MAPS

1. Neuchâtel and Switzerland in the early modern period 28

2. The principality of Neuchâtel and Valangin 29

\section{TABLES}

1. Matrimonial litigation, 1547-1706 58

2. Marriage contract disputes, 1547-1706 98

3. Illicit sexuality in Valangin, 1547-1706 100

4. Illegitimate births and deflowered plaintiffs in Valangin, 1547-1706 101

5. Grounds cited in divorce suits, 1547-1706 123

6. Police actions against married persons, 1547-1706 151

7. Matrimonial litigation, 1707-1806 174

8. Illicit sexuality in Valangin, 1707-1806 178

9. Illicit sexuality in the city of Neuchâtcl, 1707-1806 179

10. Marriage contract disputes, 1707-1806 201

11. Divorce cases, by gender of plaintiff, 1707-1806 223

12. Grounds cited in divorce suits, 1707-1806 225

13. Suits for judicial separations, 1707-1806 245

14. Police actions against married persons, by gender, 1707-1806 253

15. Police actions against married persons, by cause, 1707-1806 254 
